\title{
The Practice of Local Wisdom of Dayak People in Forest Conservation in South Kalimantan
}

\author{
FAHRIANOOR, TRI WINDARI, TAHARUDDIN, RUSLIMAR'I, AND MARYONO
}

\begin{abstract}
The research is conducted in the purpose of discovering the practice of local wisdom in Dayak people in their interaction with the forest. The research is also conducted using qualitative method, conceptual foundation focusing on local wisdom based in the community of Dayak Upau, Dayak Warukin and Dayak Loksado. The result shows that the practice of local wisdom in preserving the forest is by treating the nature in the way as treating the people themselves. The practice of local wisdom by the Dayaks is implemented in the forms of livelihood, social values, their knowledge and belief.
\end{abstract}

Keywords: local wisdom, forest, dayak people

\section{INTRODUCTION}

Kalimantan island is one of the five biggest islands in Indonesia, even the third biggest in the world after Greenland and all papuas. South Kalimantan consists of $73 \%$ of land. The rich forest Kalimantan Island consists of four provinces, i.e West Kalimantan, Central Kalimantan, South Kalimantan and East Kalimantan. (Mackinnon, dkk, 2000 : 1).

Tropical forest in South Kalimantan results abundance of forest commodity which is beneficial for the surrounding inhabitants. However, the rich commodity of the forest cannot be fully enjoyed by the local people. The main cause is that the forest is already divided by the government and has been given to business sectors. In 1990 the forest was given to the business having the rights to use the land/forest concession (HPH), while in 2000 up to the present the forest is already transformed into palm plantation (Pilin, 2002:59) as mentioned in Act No. 5 of 1960 The Basic Provisions Concerning The Fundamental of Agrarian Affairs that Agraria/ State Land Division has the authority to take the independence and the rights of local people that have been arranged in the traditional law. The authority of using the land has been in the hand of central government since then.

Correspondence : Fariannor, FISIP Lambung Mangkurat University, Banjarmasin, Indonesia
The presence of Basic Agrarian Law Act No.5 year 1960 is used to legitimate the government to take control all traditional rights on forest which means it is taken by the state. The local community has also been blamed for destroying the forest by exercising the shifting field agriculture system.

As widely known, the life of the people around the forest cannot be separated from forest as their part of social life. Forest plays an important role in life of Dayak People. The importance of forest to the Dayaks is because it greatly support their daily lives. The Dayaks is generally known as a community living in remote areas of South Kalimantan by depending their lives on farming implementing shifting field agriculture system.

Dayak ethnic group consists of 450 subtribes and they inhabit all areas in Kalimantan as described by Maunati (2004: 60, in Lahajir 1993) that in the beginning all the subtribes were parts of the same group and due to geographical and demographic process which lasted for a thousand year, this group was divided. There are still similarities caused by the same origin, which is the Yunan province.

Apart from the origin of Dayak ethnicity, the reality shows that Dayak tribe is a tribe lives in forest area as their social activities.Dayak tribe has its own understanding of forest, as seen in the life of Dayak Bukit. In the tradition of Dayak Bukit there is a term called sumbayang ceremony (prayer) to paddy/rice, sumbayang to 
gods conserving the paddy that protect the land and trees and also sumbayang to ancient spirits who have already given the ways to do a well agriculture technique (Radam, 2001:246). For DayakUpau and DayakWarukin who live in Tabalong District and Dayak MeratusLoksado in Hulu Sungai Selatan District, forest and land are the source of life. For this tribe, the function of forest is always connected to the traditional law and authority.

Having analyzed the reality in Dayak life and the destroyed forest in Kalimantan, it is obvious that HPH (forest concession) and palm plantation business that use technology impact the destruction of environment in the forest, moreover by implementing this HPH, the foreign exchange increases considerably.

As mentioned by Aris (1993:38) the social and cultural impact of HPH implementation towards the local community transforms them prioritizing the financial competition. The culture of working together (gotong-royong) which is applied inherently considered to be ineffective and does not have an economic value. The tradition of working in the field starts to be left as it is considered to be unpractical. It means that the HPH business has already changed the traditional values of Dayak Upau, Dayak Warukin and Dayak Loksado people that had lasted for years as the legacy of principles, the way of life and knowledge.

However, the expression is contradictive as people tend to believe that Dayak ethnic group is a group that keeps the local tradition and has local wisdom values manifested in the way they treat the forest environment. The Dayak ethnic groups in Kalimantan believe that the treatment to nature is also a treatment to themselves (Radam, 2001:168). This understanding implies in the tradition and knowledge on how they manage and preserve the forest environment.

The concept of Local Wisdom. Local wisdom, in the context of development or environment conservation is often addressed as the discourse for policy practitioners and academicians, and it is always connected to the efforts to overcome the global issues on disadvantage situations for the third world. When the third world countries are blamed as nature destroyers, they argue that they have its solutions as having values in preserving the ecological balance. The values ofthis community is named as a form of local wisdom. Local wisdom is a skill or strategy to manage the cosmos in the face of human being and to maintain the ecological balance which has been centuries tested by natural disasters and constraints and also by the careless acts of humans (Wahono, et all, 2001:viii).

Another argument on local wisdom is related to activities of the community, especially in relation with interaction towards the nature. Sutanto (2001:76) states that in traditional agriculture, there is one important aspect called Local or Indigenous Knowledge (IK), or is often addressed as local/traditional wisdom. Pawluk (1992) in Susanto (2001:77) mentioned that the local wisdom system in agriculture is a comprehensive knowledge and develops in a certain ethnicity or culture to fulfill the life needs in subsistent way in accordance to the existing environment condition.

Both the concept of local wisdom and traditional wisdom refers to the concept of knowledge and a set of values applied in a traditional society. Hadiyoko and Panggih Saryoto (2001:183) mentioned that the term of traditional wisdom is often used to distinguish two systems of technology development and knowledge. The term does not refer to the very ancient system of knowledge, but rather refers to a technology system and knowledge which is based on society.

Keraf (2002:289) has almost the same understanding of local wisdom based on knowledge by proposing a concept of local wisdom which contains the meaning that all forms of knowledge, belief, and understanding or perception, which also includes customs or norms lead the attitudes of mankind in the life of ecological community. Therefore, according to Keraf, traditional wisdom is not just about the knowledge, understanding and customs on human beings, nature and how to develop a relation amongst all inhabitants of the 
ecological community. All traditional wisdom is understood, applied, taught and inherited to generations that it also creates a set of attitude pattern in daily life of mankind, amongst themselves and towards the nature and the Almighty.

That concept is scrutinized into five more basic comprehensions. According to Keraf (2002: 289-291) firstly, traditional wisdom belongs to the community, as it is known as the knowledge about human being, nature and the relation in the nature. The aspects of traditional wisdom also belong to the community. No traditional wisdom is individualistic. Secondly, traditional wisdom, it also means practical traditional knowledge, or how the "knowledge of how". The knowledge and wisdom of local community is knowledge on how to live well in ecological community, therefore it includes how to treat every aspect and life in the universe in a way to preserve all lives. That is why there are always rules in the forms of interdiction or taboo on how to live the life. Thirdly, traditional wisdom is holistic as it includes the knowledge and understanding of all lives and interaction in the universe. The universe is "a life net" which is larger than "the number of all separated elements inside". The nature is a unity of all interconnected relations so that understanding and knowledge on nature should be one single whole unity. Fourthly, the foundation of traditional wisdom is moral activity guided by and based on moral principles or taboos sourcing from traditional wisdom. The activity cannot be explained rationally using Cartesian science standard. Fifth, traditional wisdom is local, as it relates with a particular place and concrete. Traditional knowledge and wisdom always deals with a particular life of mankind (the local community itself), nature (the environment surrounding the area they live, including tress, caves, mountains, lakes, and the sea) and the relation with the nature.

It can be seen that knowledge and technology model are maintained by the local people to cultivate the nature through generations. The nature balance is kept well based on local wisdom. Knowledge and strategies applied by generations are in accordance to tradition and social values in the ethnic group and traditional community in order to fulfill the daily needs. It cannot be separated from the context of morality with the people and the perception of indigenous people towards the nature and its relation with humankind.

The concept of local wisdom explained by Keraf is relevant to be the foundation of the research on Dayak Bukit in order to preserve the forest in the area they live. Dayak Bukit people significantly depend on the forest and their agriculture system in their daily life.

\section{MATERIALS AND METHODS}

The method used in this research is qualitative method. The data is collected and arranged systematically (Isaac and Michael, 1981: 46, inRahmat, 2001: 27). The purpose of the research is to analyze local wisdom amongst Dayak ethnic group.

The research is focused on Dayak community who geographically lives in the hill areas. This category is chosen by considering the level of difficulty if the research is done based on race or sub-race, Dayak ethnic group consists of numbers of variety in race and subrace, which is highly difficult to analyze.

Radam (2001:100) also mentions that the people of Dayak Bukit experience isolation but still maintain strongly their local tradition as the characteristic of a close community. In this case, the in-group feeling is very strong and this is the cause of bubuhan (a large family virilocal or utrolocal) has a stronger meaning than the family umbun (family based on blood line). At the same time, recently Dayak Bukit community develops several ways of living, i.e gathering the yield of the forest (resin and rattan), shifting-field agriculture system, agriculture and rubber farming. Working in the field shifting system is a legacy of their ancestors.

Having known the concept, Dayak ethnic group is easily recognized. Radam called it as the people of the hill, however for most HuluBanjarese they are known as the people of 
Dayak. It was stated by TjilikRiwut (1979 : 219) by explaining that the people of the hill (orang Bukit) are in the category of Dayak Ngaju ethnic group. It shows that the people of the hill who inhabit along the Meratus mountains in South Kalimantan are Dayak ethnic group, while there are others who live along the river and live a life that cannot be separated from the forest.

The data is collected in two ways. (1) Literature study where the data collecting and relevant theories in this research are conducted using written sources and materials as the frame work of research. The literature study is obtained from books related to the topic as well as documents, bulletin, journals and other supporting sources. (2) Field observation, which is conducted in two ways as commonly done in qualitative research, which is through direct observation. The function of observation in qualitative method is to describe details of the problems and preliminary process in gathering the information. It is done in nonparticipatory observation which focuses on the points of concept framework and the points related to the concept of local wisdom.

Interview is done to get data and further information. Interview guide is the instrument where interviewers are not strictly limited by instrument, but rather it can be developed according to the condition. Photographs of daily life of Dayak Upau, Dayak Warukin and Dayak Loksado are taken to support the data.

The unit analysis taken is individuals and institutions. Therefore, the interview is addressed to key persons such as local government and traditional institutions of Dayak who deals with the forest. However, the interview is also done to individual members of the community, especially the ones whose life connect directly to the forest.

Data analysis contains sub-theme as explained in the framework concept, i.e dealing with local wisdom of Dayak Tepian Sungai and Dayak Bukit from the point of view a) economic system; b) social values; knowledge system and; c) religion. All is presented to illustrate local wisdom owned byDayakTepian Sungai and Dayak Bukit, and also to analyze the dynamics of the wisdom. Process analysis is carried out by data clarification based on data source, and sub-theme is used as its concept framework which connects it to theories applied.

\section{RESULTS}

Local Wisdom of Dayak towards the Nature. DayakUpau, Dayak Warukin and Dayak Loksado have the same understanding that universe is the creation of Datu Adam and Datu Tihawa. They believe that nature has similarities with human beings. For instance, the land is the flesh, small stones are bones, big and small trees are the hair on human's head and other body parts. The high and short mountains are the head, hands and feet. The caves in the mountains are lips and stomach. The roots are the muscles. Rivers and water fountains are the pulse and blood vessels. Valleys and cliffs are the wrinkles on the body. The wind blowing slowly is the tranquil breath of humankind while the cyclone is a restless breath.

The concept of the divines in pursuance of Dayak Upau, Dayak Warukin and Dayak Loksado. In the myth of the Dayaks, there are only two gods known as Suwara and Jabaril. Suwara is the creator of the first human origin. Therefore the phenomenon in the universe is due to the enlargement of movement and biological urge of Datu Adam and DatuTihawa.

The Dayaks have the concept that God living in the sky is the owner of the sky and the universe. Guguhan or Suwara is also called as Panglangit who has the meaning as the father of the sky. Panglangit has the power to guide people towards the signs and phenomenon of nature as the lightning, thunder, etc., so that he is also named Panglangit Basuwara (the speaking father of the sky).

Panglangit is also believed as the origin source of all things, on earth and all others in the universe. Panglangit is the source of life for mankind and a source who gives wealth to all creatures on earth. Panglangit lives in the highest layer of the sky that is also the place of 
Datu Adam and Datu Tihawa together with Nining Bahatara.

Thus the divine concept of the Dayaks has three primary gods and a number of gods who are not primary or companions. Suwara is the creator of the universe origin and the first human, i.e. Datu Adam and Datu Tihawa. Under him, there are gods that rule and maintain the nature, villages, fields, animals and vegetation. Nining Bahatara is the god who manages wealth and decides the destiny of people. Under Nining Bahatara, there are gods in the form of spirits of Datu Nini who regulates tradition and the Dayaks culture.

The Forms of Local Knowledge of Dayak Upau, Dayak Warukin and Dayak Loksado

\section{The livelihood of Dayak Upau, Dayak Warukin and Dayak Loksado}

As it is found in other communities, the Dayaks also have a specific way to support their lives. Their livelihood can be divided into three categories, i.e farmers by implementing shifting-field agriculture, rubber tappers, and food gathering.

\section{a. Shifting-field agriculture system}

The model of livelihood done by the Dayaks in Kalimantan for years is mainly field agriculture. In the life of the Dayaks, field agriculture is not just a matter of economic aspect, but it is also a manifestation of culture in the community. This is built upon the process of opening the field under the obedience of certain rules.

The process of doing shifting field agriculture cannot be separated from forest as the main source. Farmers definitely need forest, but the capacity in opening the forest is relatively limited. However, the dependency of the people in fulfilling the daily needs is extremely high. The livelihood of the Dayaks which generally connects with the forest can be seen not just in carrying out the field agriculture, but also in other ways of fulfilling daily needs such as taking honey from trees, gathering rattan and tapping the rubber in the forest.

The Dayaks also work in farming which is generally rubber, candleberry tree, fruits as durians, cempedak (mini jackfruit) and others.
Thisvegetationis types of forest vegetation. This way of life has been done for generations, which is a reflection of an interaction between forest and Dayak community.

As explained by Sopiyan, a Christian priest in Dayak Upau community:

"The number of Dayak Upau people who still carry out the shifting field agriculture is $75 \%$. Generally, they open a field in a covert/dense forest. However, there are people who open the field in an area they had already used before for planting rubber trees. The cultivation of shifting field agriculture in a newly opened field usually done in two years, which is then the area, is planted by rubber trees or fruit trees." (interview on 12 October 2012)

The expression strengthens the comprehension that forest is the source of life for Dayak Upau. Thus they plant rubber and fruit trees so that the forest can be restored. It is also argued by Hermen I. Ngenda, a member of Dayak Upau ethnic group:

"The people of Dayak Upau really depend on forest because the majority of peopleis field farmers. Rice is the main earning even though they also cultivate other field type plants such as corn and banana. Rice as the main plant should be worshipped according to Kaharingan belief as it is believed to be the food of sacred people." (interview on 12 October 2012)

The same way of life is also found in DayakWarukin and DayakLoksado which are the sub-ethnic group of DayakMaanyan. The people of Dayak Upau and DayakLoksado generally open the untouched forest, but the people of Dayak Warukin generally open the field in a rubber forest where we can find other plants not merely well cultivated rubber trees. It is as described by Sikin, the traditional leader of Dayak Warukin:

"The majority of livelihood of Dayak Warukin people is farming. The type of farming is bahuma (working in the field). This is because they live in a protected forest which is by the traditional rule is perceived as sacred, thus the local people 
open the field in rubber forest which has been cultivated for years or in an area in the rubber forest where they commonly refer to as pohongatahtuha (unproductive rubber trees). The farmers in this area normally plant local rice type which can be harvested within 5-7 months."(Interview on 11 October 2012).

In Dayakcommunity, the farming is known as bahuma. The perception of shifting field agriculture that is the base of economic system in Dayak Upau, Dayak Warukin and also Dayak Loksado, has the main element which is forest. This is due to the belief that a newly opened field has the highest fertility since it was a forest. If the level of fertility is decreasing, they should open another forest to make a field.

In the process of opening the field normally all members of the family are involved, often the close relatives give a hand. There are several steps commonly taken by the Dayaks, as explained by one of the traditional leaders:

"those steps taken are: (1) chopping the bush. It is normally done by the men and women using simple tools as long chopping knife/parang and machete, (2) cutting trees which is done by men using ax or belaying. The trees cut are being left to get dry at least 2 months. (3) in dry season, the dry leaves and branches are burned by the men at the time when all boundaries of the area are cleared in order to prevent the fire to get everywhere in the forest. (4) after the burning process is finished, fences are made around the field and the hut is constructed. The fence is made to protect the field from animals destroying or eating the rice and other plants. (5)the men and women left the field to get ready to cultivate. (6) using tugal (a sharp pointed pole) where the men make holes on the ground and the women fill up the holes with seeds.(7) the next step is when the rice plant is already 3 month old, they do penatatan (weeding). (8) after 4 months of planting, the rice is harvested together. (9) the harvest ceremony is being held. (10) clearing up the again the field to plant other vegetation.(interview on 5 October 2012)

This process is a common process generally done by the farmers of shifting field agriculture each time they open a new field. Nevertheless, in the next step, especially in the second cultivation, cutting trees and burning process are not executed. Therefore in the second and third year there are only eight steps carried out. When the level of fertility is decreased, they start looking for another area. However, before leaving the field, they plant rubber and fruit trees, just as described by HermenI.Ngenda:

"That we, Dayak Upau people in cultivating the land in shifting field agriculture take about 2-4 years and before leaving the land we should plant rubber trees. The process of planting the trees has actually been started sincemenatat (weeding). We do not leave the land just like that, rubber plant is a choice as it contributes to our earning". (Interview on 12 October 2012)

This explanation is also not different from the explanation of a traditional leader of Dayak Warukin who describes that:

"In the tradition of DayakManyaanWarukin, bahumais done at least 2-4 years. Along time ago before leaving the land, they did not plant anything, but since several decades they should plant trees before leaving the area such as rubber or fruit trees.' (Interview to Sikin on11 October 2012)

Both shifting field agriculture models exercised by Dayak Upau, Dayak Warukin and Dayak Loksado are the same. They all replant on the areas they had opened. It relies on the belief that their lives depend on forest and that they should maintain the balance of nature.

Rotation is done in order to restore the quality of land. It is because the phase of rubber productivity also has an optimal production which takes around 7 up to 25 years. The Dayak people are really aware of the land value they cultivate.

It can be seen from the picture the remains of the cutting trees and burning process done by Dayak Upau. It can also be found in agriculture system done by Dayak Warukin. In the picture, the rice plant is having a process of 
ditugal (putting the seeds in the holes) by the Dayaks. This practice has been done for years, inherited by the ancestors.

\section{b. Rubber Tappers}

Another way of life of Dayak Upau and Dayak Warukin people is rubber tappers. That is why their life is very close to forest. Local knowledge of Dayak Upau and Dayak Warukin can also be seen in the process of planting rubber trees and tapping gatahpara(latex). Tapping the rubber is done by the Dayaks for generations.

Incising the latex (heveabrasiliensis) growing in the wild is also another way of life. The activity of incising and tapping the rubber is done by the father, mother and as well as the children. Almost all members of the family in Dayak Upau, Dayak Warukin and Dayak Loksado work as rubber tappers. According to information from Sikin (the traditional leader of Dayak Warukin):

"the activity of tapping the rubber done by Dayak Warukin people is under the knowledge of maintaining and cultivating rubber plants. The people really avoid superior types of rubber plants introduced by government through the department of plantation, Tabalong Local Government. It is under consideration that those types have many weaknesses; amongst others, are abundance of water content, irresistible to plant diseases, and generally have a short life period." (Interview on 11 October 2012)

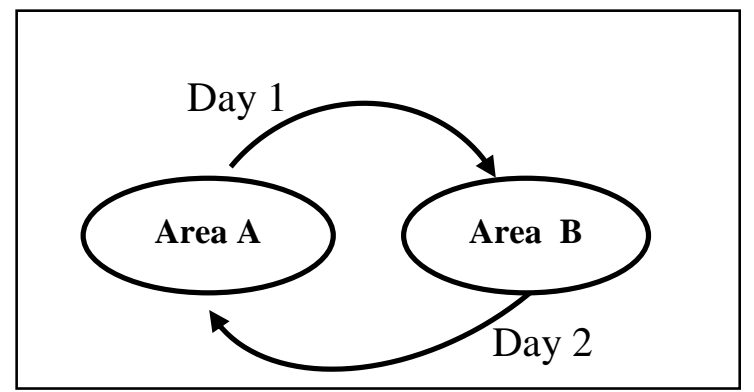

Figure 1. The model of taking turns in tapping the latex

this community, it is clearly shown that the Dayaks have experience that shapes their knowledge about rubber plant they cultivate.
Living in a life closely to forest, the Dayaks have rules applied for generations. By and large every traditional leader of Dayak Upau, Dayak Warukin and Dayak Loksado has at least two areas of rubber cultivation which is 2-3 hectares each.

They exercise the rule of not tapping the latex everyday but taking turns in order to keep the trees in well condition. If the tapping is done every day in the same area, the latex obtained is less that automatically the production is decreased. Figure 1 shows the model of tapping the rubber system performed by Dayak Upau and Dayak Warukin.

The rubber tapping like this is proven to be able to preserve the trees up to decades, even though the trunks keep being tapped. In most cases the Dayaks do not just have one or two areas of rubber cultivation, but some. It is because they inherit them from the forefathers and they also open a new field in a system of shifting field agriculture. Mostly it is found in Dayak Upau community as they live in subdistrict Upau, an area that still has forest area.

The activity of tapping the latex will be hindered if the rainy season comes. It is because the latex mixed with water will reduce its quality and it will get frozen in small pieces like seeds or known locally as kakacangan (look similar to peanuts).

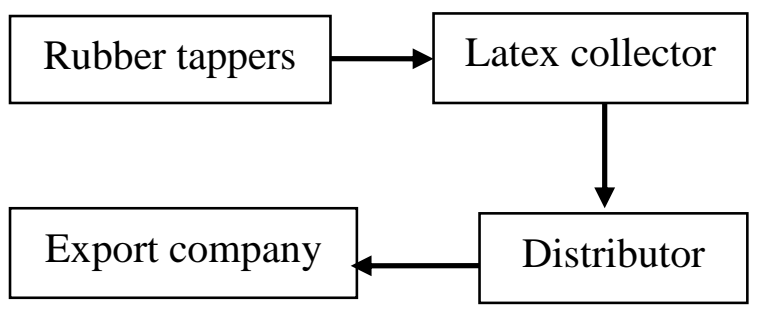

Figure 2.The chain of latex trade system

Therefore in rainy season the Dayaks prefer to cultivate the land by bahuma (planting the rice).

The economic benefit from tapping the rubber for Dayak Warukin and Dayak Upau reaches $R p 12,000$ up to $R p 13,000$ per kilogram. The daily income depends on the weight of the latex. In most cases, the Dayaks are able to Figure out how many kilograms they can get for each area. Generally the latex they can yield daily is about $10-15 \mathrm{~kg}$. Having 
calculated $10 \mathrm{~kg}$ x 12,000 , we can get 120,000 daily. In a month usually they tap only 24 days, in every market day they should sell one time a week, so that the income per month is $\mathrm{Rp}$ $120,000 \times 24=\operatorname{Rp} 2,880,000$. In sub-district Upau, the market day is every Friday and in sub-district Tanta it is on Thursday while in sub-district Loksado it is on Wednesday. Normally the buyers come directly to the sellers or latex collectors. Then these buyers will resell latex to bigger sellers/latex collectors.

The chain of latex trade system is the same in those three Dayak communities. This trade system has been carried out for long period and the latex farmers never feel being disadvantaged by this trade system.

\section{DISCUSSION}

Rain is considered as sweat, fog is the body vapor taking a bath in the morning. Lightning and thunder are the cough of humans, and natural disasters are the shapes of human's quarrels. The human mentioned is Datu Adam and Datu Tihawa. So the nature is considered as a living human being. All the nature's phenomenon is the attitude results of Datu Adam and Datu Tihawa. This attitude is then inheritby humankind through generations. Consequently, the treatment towards nature is the same as the treatment to oneself.

Dayak Upau, DayakWarukin, and Dayak Loksado also believe that substances of nature, organic and non-organic, are the soil, water, fire and air. It is believed that the sky is something bright, thereof it is seen as something having light which is fire, and it is believed as having a close element in the life of humans.

Dayak Upau, Dayak Warukin and Dayak Loksado also believe that even though there is a distance between the earth and the sky; both are connected by the pillar of aras. The concept of arasis a concept based on the influence of BanjarHulu ethnic group who perceive the term aras as a place of God, therefore this concept implicates the exercise of ceremonies. There are numbers of ceremonies' materials identified as pillars, such as tihangbabuah, tihangkuasa, tihangbahatara. The term ofaras pillar is a also a concept of Dayak Upau, Dayak Warukin, and Dayak Loksado about the world over and the underworld. The earth is perceived as the underworld and the sky is the world over. As something in a higher position, the sky is also considered as having layers. According to the belief of Dayak Upau, Dayak Warukin and Dayak Loksado, the sky has seven layers with its peaks each.

In order to reach the sky, people should climb up the ladders. There are six ladders; the eighth ladder is the highest ladder. In order to go up to the sky, ceremonies should be held by balian. It is only balian who has the capability to invite the spirits from the sky. The smoke of incense mixed with the spells of the balian is the ladders to take people to the sky. This ladder is known as tangga balian/the ladder of balian.

For the Dayaks, the bottom part of the sky is inhabited by spirits and guardian angels that keep and manage the emergence of nature's phenomenon, the regular and the extraordinary ones, such as natural disasters and the seasons. While the sky in seventh layer is inhabited by Datu Laki Bandansanak Walu and Datuk Langit Bandansanak Walu together with Pangguruan, a spirit of baluan guru jaya.

The concept about nature in Dayak community is a concept began with the perception that the treatment to nature is the same as the treatment to oneself. The universe is considered as having characteristics as humans. This concept is a concept of local knowledge.

\section{CONCLUSION}

The practice of local wisdom performed by Dayak Upau, Dayak Warukin and Dayak Loksado shows a similar pattern. This pattern is expressed in the interaction of the three groups of Dayak community which is based on the same understanding of the same way to treat forest and humans. The universe is considered as the manifestation of Datu Alam and Datu Tihawa. The belief of the Dayaks is reflected in 
the form of the way they support their lives, their social values descended for generations, as well as the knowledge and tools supporting the work. The livelihood of Dayak Upau, Dayak Warukin and Dayak Loksado is field farming, rubber tapping, and food gathering, which is based on forest.

\section{REFERENCES}

Aris, A.Y, 1999, Pengalaman Masyarakat Adat Dalam Memperjuangkan Hak-Haknya, Volume 1, Jurnal Hutan Rakyat

Keraf, A. Sonny, 2002, Etika Lingkungan Kompas, Jakarta

Maunti, Yekti, 2004, Identitas Dayak Komudifikasi dan Politik kebudayaan LkiS, Yogyakarta

Radam, Noerid Haloei, 2001, Religi Orang Bukit, Semesta, Yogyakarta

Rahmat, Jalaluddin. 2001, Metode Penelitian Komunikasi, Remaja Rosdakarya, Bandung

Riwut, Tjilik, 1979, Kalimantan Membangun, Jayakarta Agung, Jakarta

Susanto, Rahman, 2000, Tantangan Global Menghadapi Kerawanan Pangan dan Peranan Pengetahuan Tradisional dalam Pembangunan Pertanian. Dalam Wahono dkk, Pangan Kearifan Lokal dan Keanekaragaman Hayati, Cindelaras, Yogyakarta

Sutanto, Rahman, 2000, Tantangan Global Menghadapi Kerawanan Pangandan Peranan Pengetahuan Tradisional dalam Pembangunan Pertanian. Cindelaras, Yogyakarta.

Wahono, Francis, dkk, Pangan, kearifan local dan keanekaragaman Hayati, Cindelaras, Yogyakarta. 
Journal of Wetlands Environmental Management

Vol 1, No 1 (2013) 33 - 41

http://dx.doi.org/10.20527/jwem.01.01.01 